\title{
Committees as strategic practice: The role of strategic conversation in a public administration
}

\section{Christina Hoon}

ABSTRACT This longitudinal qualitative study examined the role of committees as strategic practice during the implementation of personnel development in a public administration. The results show that the interaction between the management levels is not only organized in formal committees where the middle managers undertake strategic initiatives and the strategic context is set by the senior managers. Rather, the middle managers and the senior managers organize the discussion on strategic issues in informal interactions around committees. These close informal interactions can be understood as a strategic conversation that entails the micro-mechanisms of generating an understanding, aligning towards an issue and making prearrangements which give support for the flow of discussion. The findings show that the strategic conversations are beneficial within shaping strategy as they frame the committee as strategic practice and enable the strategic context to be reshaped and redefined.

KEYWORDS

committee $\boldsymbol{~}$ interactions $\boldsymbol{~ m i d d l e ~ m a n a g e r s ~} \boldsymbol{~ s t r a t e g i c}$

conversation - strategic practice - strategizing

Current trends in strategy literature focus on the strategic importance of middle managers where they are not only viewed as conduits of senior managers' orders, but as strategic assets who play a pivotal role in strategic changes (Balogun, 2003, 2006; Dutton et al., 1997; Hart, 1992; Huy, 2001, 
2002). From the perspective of middle managers, it is suggested that the senior management is the architect of an overarching structural context, while the middle managers select promising initiatives and give strategic input from the bottom-up (Bower, 1970, 1997; Burgelman, 1983, 1996; Hart, 1992). The strategizing activities of middle managers unfold within this overarching structural context, in which the middle managers interpret senior management's activities as an attitude towards a strategic issue that legitimizes continuing on with a strategic issue (Dutton et al., 1997, 2001, 2002). In championing strategic issues, middle managers have the potential to redefine the strategic context and to reshape the strategic thinking of senior management (Bartlett \& Ghoshal, 1993, 1995; Floyd \& Wooldridge, 1992, 1997). Although this interaction between senior and middle managers, which is viewed as the redefinition and reshaping of the strategic context, is important for creating an understanding about strategic change (Balogun \& Johnson, 2004, 2005; Gioia \& Chittipeddi, 1991; Gioia \& Thomas, 1996; Gioia et al., 1994; Isabella, 1990), not much is known about how these interactions unfold.

As a result, we know little about the managerial activities and managers' interactions on multiple levels as most studies focus either solely on senior managers (e.g. Datta \& Rajagopalan, 1998; Jarzabkowski, 2004; Samra-Fredricks, 2003) or on middle managers (e.g. Balogun, 2003; Balogun \& Johnson, 2004; Currie, 1999; Dutton et al., 1997; Huy, 2001, 2002). Of those few studies conceptualizing about interrelationships across multiple levels, they are largely theoretical focusing on strategic roles (Floyd \& Lane, 2000) or categorizing different levels by their strategic actions and tasks (Burgelman, 1983, 1996; Mantere, 2005; Regnér, 2003), rather than examining managerial interactions. Therefore, recent studies suggest advancing research on middle and senior managers and their interactions in strategic change by examining their ongoing daily activities (Currie \& Brown, 2003; Johnson et al., 2003; Rouleau, 2005).

This interest in managerial activities and the need to understand more about how middle and senior managers interact and influence strategic activity is supported by research about strategy as practice. The strategy as practice perspective refocuses research on the actions and interactions of the strategy practitioners and the situated practices they draw upon in doing strategy (Balogun et al., 2007; Jarzabkowski et al., 2007; Johnson et al., 2003; Whittington, 1996, 2003, 2006; Whittington et al., 2003). This includes not only a focus on managers but also on particular patterns in strategizing activities such as routines and artifacts present in a social context (Brown \& Duguid, 2001; Hendry, 2000; Jarzabkowski, 2003, 2004, 2005; 
Jarzabkowski \& Wilson, 2002; Johnson \& Huff, 1998). The strategy as practice perspective suggests that shaping of strategy is not wholly dominated by top managers and their top-down activities and thus proposes a broader conceptualization of strategic practitioners on different management levels, all of them having an important impact upon strategy (Burgelman, 1983; Currie \& Brown, 2003; Johnson et al., 2003; Rouleau, 2005).

This article takes on this challenge and examines the interactions between senior and middle management levels by focusing on formal events within strategic decision-making processes. These formal events are particular recurrent strategizing activities or episodes in strategic change (Hendry \& Seidl, 2003; Jarzabkowski \& Seidl, 2006). The formal events refer to recurrent meetings, processes, and traditions that are central to strategy formation and implementation as they structure the flow of everyday strategy work (Mantere, 2005). This article focuses on a particular type of formal event: it analyzes the interactions of strategists within a committee. A committee is defined as a particular group of people put together to work out an issue. In formally scheduled committee meetings, this group of people explores a strategic issue, makes recommendations on this issue, and implements a particular initiative. The central argument in this article is that in order to better understand strategy implementation, one must consider the strategically relevant actors and their interactions within and around committees.

Therefore, this article draws on a real-time case study of a large public administration to investigate the interactions that shape strategy implementation. From a managerial perspective, the findings expand on what is known about middle managers and top managers as strategic practitioners, especially in terms of their interactions across multiple levels and explain how these interactions are organized. This article addresses the interactions of top managers and middle managers within formally scheduled committees and the informal interactions around committees in four sections. First, the previous studies are presented which examine the different roles managers play and their formal and informal interactions between management levels. Second, the methodology and the research field are discussed. This section includes the research methodology and the description of the single case study dealing with the implementation of personnel development in a public organization. The findings concern the strategizing activities of top and middle managers within committees, the strategic conversation as a specific informal interaction 'around' formal events, and the implications of strategic conversation for shaping strategy implementation. The article finishes with a discussion and implications for future research. 


\section{Conceptual background}

Based on an interacting perspective, strategies present themselves as a pluralistic process emerging from the intertwined activities of managers at different levels (Bower, 1997; Dutton et al., 1997, 2001; Hart, 1992). A major component of strategy research has been the identification of the strategic roles played by each level of management (Bartlett \& Ghoshal, 1993, 1995; Floyd \& Lane, 2000; Floyd \& Wooldridge, 1994). The strategic roles involve a specific type of acquisition and exchange of information related to environmental change and the organization's response to it. The aim of these studies is not just to understand how management plans and how actions are created, but also how these plans are influenced by all managers involved, and how they are translated into the day-to-day practices that create strategy and initiate change (Balogun et al., 2003; Hendry, 2000; Johnson \& Huff, 1998).

\section{Strategizing activities of senior management and middle management}

With regard to the interactions between the management levels, middle managers are viewed as strategic assets playing a central role in strategic changes (Balogun, 2003, 2006; Dutton et al., 1997; Floyd \& Wooldridge, 1992, 1997; Hart, 1992; Huy, 2001, 2002). By injecting divergent thinking and change-oriented behavior into shaping strategy, middle managers can play an important role, because they have the potential to affect the organization's alignment with its external environment (Floyd \& Wooldridge, 1994, 1997). Balogun (2003) identifies middle managers as change intermediaries fulfilling several interrelated implementation roles. It is suggested that middle managers' interpretation of the intended change is the key task for their intermediary position, since it informs all their implementation roles (Balogun, 2006). Moreover, middle managers are suggested to be central, because they supply the required contextual knowledge and experience for shaping strategy (Dutton \& Ashford, 1993; Dutton et al., 2001). This knowledge may be a form of practical expertise about the norms and behaviors appropriate to the organization and how the organization actually works. The high level of contextual knowledge and experience enhances the middle managers' ability to champion strategic issues and contribute to a firm's strategic direction (Floyd \& Wooldridge, 1992, 1997; Regnér, 2003; Thomas \& Dunkerley, 1999). Championing is defined as when individuals try to influence the organization beyond their operative responsibilities to affect strategically important issues (Howell \& Boies, 2004; Mantere, 2005). To champion strategic initiatives, the middle managers use the resources at their 
disposal and opportunities to bring an innovative issue onto the agenda of the organization (Dutton \& Duncan, 1987; Dutton et al., 2001). In particular, the middle managers use specific tactics to sell strategic initiatives as a means to ensure that the upper management devotes attention to an issue and takes action on it (Dutton \& Ashford, 1993; Dutton et al., 1997, 2001; Wayne et al., 1997).

Although the literature offers a number of different perspectives on the roles the management levels play within shaping strategy, this study puts more emphasis on the interaction between both managerial levels and how their close interaction is organized. Interactions are characterized as emerging from the intertwined activities of managers on different levels and include the distribution of information such as exchanging information and communicating both vertically and horizontally (Balogun, 2003; Forbes \& Milliken, 1999). Interactions represent some degree of involvement through the participation and support of those involved in the process. Moreover, interactions also play a role in decision-makers' interpretations, because interactions serve to translate events, instill meaning in these events, and develop shared understandings and schema about these events (Gephart, 1991; Isabella, 1990). The interactions can contribute to developing a new understanding by enhancing the exchange of goals, visions, plans, alternatives, and accounts of past experience. When faced with new issues, managers have to make sense of what is going on around them and determine if and how they should respond. Sensemaking is a process through which people create and maintain a subjective world and it plays a central role in cognitive reorientation (Gephart, 1991, 1997; Gioia \& Chittipeddi, 1991; Gioia \& Thomas, 1996; Gioia et al., 1994; Thomas et al., 1993). However, not only senior managers create meanings about strategic change and negotiate it with organizational members. Thus, recent studies suggest that the creation and diffusion of meaning surrounding a strategic issue is also part of middle managers' work (Balogun \& Johnson, 2004, 2005).

\section{Sites of interactions between strategists}

To better understand how the interactions between management levels are organized it is helpful to focus on the strategic practices that strategists use in their daily strategy work. Strategic practices can be understood as particular types of recurrent strategizing activities within strategy shaping such as recurrent meetings, workshops, processes, and rituals (Mantere, 2005). As these formal events deal with certain topics, the events determine which participants are to take part, which issues are to be discussed, or what information is to be made available. From the perspective of strategizing episodes 
the formal events can be understood as temporal points at which a switch from the day-to-day operational context into an exceptional strategic context takes place (Hendry \& Seidl, 2003). The formal events are of evident importance for shaping strategy as they are the necessary, routine part that open the way for new and unpredictable structures, and new strategic discourses. Rich and systematic research has been provided that examines formal events and the formal structure of decision-making processes in different contexts (e.g. Hart, 1992; Hickson et al., 1989; Langley, 1988, 1989; Langley et al., 1995; Quinn, 1978, 1980). With regard to formal analysis approaches, the interactions are discussed as a practice of formally organizing the analysis of and the decision about a strategic issue (Forbes \& Milliken, 1999; Fredrickson, 1986; Hickson et al., 1989; Quinn, 1980). We know that within strategic decision-making processes the recurrent formal interaction enhances systematic information brokering by distributing information throughout the hierarchy (Bartlett \& Ghoshal, 1993, 1995; Fredrickson, 1986). The formal events are purported to be an especially helpful means to formally involve all actors and to regulate divergent aims and interests (Amason, 1997; Korsgaard et al., 1995). Moreover, the well-organized and systematized interactions within formal events are functional mechanisms for managers to make sense of and interpret new issues.

While the formal events are characterized by pre-planned interactions among a particular group of actors that is set up to deliver a certain product such as a report or recommendations, the informal contacts are not formalized and do not have an official agenda. With regard to exchanging strategic issues, Dutton and Ashford (1993) differentiate between giving information in a public setting at a formal event or giving information in a private setting during informal interactions. They suggest that it is easier to gain senior management's attention and understanding of an issue when walking in the hallway than by using official channels (Dutton \& Ashford, 1993; Dutton et al., 1997, 2001). The informal setting is especially helpful to keep the senior management informed about new issues and negotiate novel proposals and innovative issues. With regard to different sites of interactions, managers participate in pre-planned, formal events or use informal interactions for changing, confirming or reinforcing strategy.

Although the strategizing activities of senior management and middle management have been highlighted throughout the literature, the mechanisms through which these formal and informal interactions are determined are an important area for future understanding. In the literature it is suggested that the senior management shapes the strategic direction and the middle managers gather strategic input where the middle managers act within an overarching strategic and structural context composed of rules, 
routines, values, and norms that provides the basis for launching further strategic initiatives (Burgelman, 1983, 1996; Jarzabkowski \& Wilson, 2002). Like other studies (Balogun, 2003; Dutton et al., 1997, 2002; Floyd \& Lane, 2000 ), this research suggests that the strategic context is not only set by the senior management. Instead, the guiding premise is that the senior management's activities are interpreted by the middle managers, while the middle managers' activities provide the potential to reshape the strategic thinking of the senior management (Floyd \& Wooldridge, 1992, 1997). Thus, the strategic context is the result of formal and informal interactions between senior management and middle management that go beyond the senior management shaping strategic direction and the middle management gathering strategic input.

The central aim of this article is to examine these mechanisms of redefining the strategic context by researching into both the formal and informal interactions between the management levels during the implementation of a strategic issue through a focus on the committee, namely, a group of people formally appointed to implement an initiative. The committee is understood as a structured and pre-determined way of conducting strategy work. While the committee is a strategic practice that formally organizes the interactions of strategic actors, the committee is framed by the various informal interactions of how managers exchange information and communicate. These informal interactions between senior and middle managers are understood as strategic conversations. Conversations are the verbal interactions of two or more people (Gephart, 1991, 1997) in which the interaction can range from a single speech act to an extensive network of speech acts that constitute arguments and narratives (Boje, 1991, 1995; Ford, 1999; Ford \& Ford, 1995). I refer to such informal interactions as a strategic conversation as it can involve political manoeuvring in terms of the activities exercised by managers to mobilize resources, to pursue strategic goals, and promote interests.

With regard to strategic conversation, this article focuses on a microlevel to explore the activities of middle managers and senior managers within shaping strategy. Moreover, the study is interested in how the interaction between senior and middle managers is organized regarding formal events such as committees in contrast to informal interactions. This also includes the question of the implications of interactions within committees as compared to strategic conversations around committees for shaping strategy. The article examines these questions by documenting, describing and examining microlevel managerial activities in strategy implementation. Using a longitudinal case study this research sets out to explore both the formal interactions in committees and the informal interactions between the senior management and the middle management and their effect on strategy implementation. 


\section{The study}

The study examined a substantial change from prior strategy in a public administration of a German university. The public administration selected for this study is a professional service organization with 400 employees that receives regulations from the Ministry of Science and is responsible for all service issues concerning a university. The growing need for more professional service and the problem of scarce resources pushed the public administration towards administrative reform which resulted in a new strategy being launched. The strategy involves a range of topics, including restructuring the administration and the implementation of economic steering instruments, such as double entry bookkeeping and a professional personnel development. The senior management of the public administration had serious doubts concerning the implementation of personnel development since it was entirely unfamiliar to the administration. Moreover, the administration was steeped in tradition and failed in past attempts at restructuring. The administration had faced entrenched power and political structures that had contributed to reform failures. However, some middle managers were interested in personnel development and subsequently, internal discussions about implementing personnel development started gradually. The middle managers began to initiate, design and implement personnel development in order to meet the aims of the reform processes and the greater demands regarding qualifications, which these processes render necessary. Implementing personnel development involved a significant change in the structure, systems, and working practices of the administration.

The first considerations about the administrative reform in general started in the Ministry of Science. With regard to the administrative reform, the public administration started a course of lectures about several issues that were relevant for the forthcoming administrative changes. Longstanding members of the administration were skeptical of efforts to implement new steering instruments. At this time, personnel development was seen by the senior management as interesting but not useful. Two months later, a cabinet decision at the political level was made which entailed the implementation of personnel development to support the forthcoming reform processes. Facing pressure from the Ministry, a group of middle managers became interested in the topic and increasingly involved in personnel development. One of the managers made a request to establish a unit for personnel development in the public administration. The request was rejected by the senior manager given the scarce resources.

However, as other public administrations started to implement personnel development, the middle managers continued to promote personnel 
development in the observed administration. The senior manager agreed to one of the middle managers attending a training program for personnel development that had been initiated by the Ministry. In order to gather more information about what personnel development is and how to implement it, the middle managers also exchanged information with colleagues from other organizations or attended conferences to develop a concept of personnel development.

The group of middle managers then asked the senior manager to invite external experts to give recommendations about introducing personnel development and its role within change processes. Instead of establishing a unit for personnel development, the expert recommended setting up a committee to plan for and to implement the personnel development. This expert's opinion helped the middle managers to justify moves that had previously been rejected and the approach was ultimately accepted by the senior management. Within the next three months, the senior management formally constituted a committee with senior management members, middle managers, and involved stakeholders. Moreover, the senior manager also appointed a group of middle managers who were actively engaged in the process thus far. While the committee had the responsibility for implementing the personnel development, the middle managers were given the task of working out the details and recommending instruments and procedures of personnel development. The primary initial task of the committee was to design the administration's strategic orientation with regard to the forthcoming reform process. In the beginning, the group of middle managers had little precedence on which to base their recommended actions for institutionalizing the personnel development. Few of the middle managers even had knowledge of the concepts and practices. Thus, the middle managers attended workshops, gathered information, and asked for help in other organizations.

Subsequently, considerable progress was made towards implementing the personnel development. The middle managers started to put forward their initial ideas for the personnel development and organized workshops, seminars, and courses. In regularly scheduled committee meetings, the middle managers presented the new concepts they had learnt from others so that all members of the committee could discuss different concepts and decide on further steps. However, the senior management was still skeptical of the efforts of the middle managers and had little confidence that personnel development could help support the current restructuring needs. Thus, the middle managers proceeded and established close contact with the senior manager to continuously present and negotiate new concepts and procedures. Due to their close contact, the middle managers finally convinced 
the senior management to formally institutionalize the personnel development. The data analysis that follows the methods section shows how this happened in more detail.

\section{Methods}

\section{Data collection}

The research focused on tracking the implementation process from the perspective of the managers involved. To develop an understanding of how strategies unfold in a public administration, a longitudinal in-depth single case study was conducted that was carried out over a period of nearly 10 years (Eisenhardt, 1989; Yin, 2003). The use of a longitudinal design enhances internal validity by ensuring that key events are accurately placed in sequences and it facilitates the detection of possible cause-effect relationships (Leonard-Barton, 1990). The research was concerned with understanding the logic behind unfolding activities which represent the underlying generative mechanisms that explain how and why observed activities occur (Langley, 1999; Pentland, 1999; Poole et al., 2000). The public administration selected for study is in the process of changing its strategic direction, pressured by the demands of the general administrative reform. The case was chosen, because it seemed to provide a rich description of a strategy process and the outcome of the process was not determined at the time of the first data collection points. Moreover, the organization provided access to all meetings and information relevant to the study. It was possible to study the work of the committee from its inception to its disbanding.

The research strategy was designed to capture the formation of strategizing activity patterns (Eisenhardt, 1989). The data included historical data as well as real-time data collected in management meetings and workshops (Balogun et al., 2003; Leonard-Barton, 1990; Richards, 2005). Because the research focused on the activities of managers, the study involved data-gathering methods such as 19 semi-structured interviews with key participants (including all committee members, stakeholders and others involved), case study write-ups, and extensive document reviews (correspondence, audit documents, briefing papers, strategic plans, reports, etc.). The interviews with all involved participants each lasted two hours on average and were taped and transcribed verbatim, yielding 142 pages of data. All participants were interviewed in German and the quotes were then translated into English. Moreover, the case study write-up yielded 113 pages and the external and internal documents provided another 480 pages. To obtain 
real-time data, 64 regularly scheduled committee meetings related to the issue were attended and observed by the researcher over a three and a half year period. Minutes and protocols of the committee as well as of other meetings related to the issue were taken. These minutes and protocols provided an additional 234 pages of data. Moreover, more than 20 informal meetings taking place outside of the committee were documented, each of them involving multiple sequences of interactions between middle and senior managers. In the cases where the researcher was involved, field notes were taken by the researcher to collect data about these informal encounters outside of the committee. To track informally scheduled encounters in which the researcher was not involved, memos were used in that one of the participating managers was asked to note, as far as possible, what was said and by whom (Miles \& Huberman, 1994; Yin, 2003). Although collecting data through participants is not without weaknesses (Balogun et al., 2003), memos are a powerful means of gathering data since they track what happens in the absence of the researcher and provide an insider's account of the situation. In sum, the rich description of the case and its findings, the close engagement with the research site during the collection of real-time data, and the use of multiple methods and sources of data collection can enhance the validity of the data (Lee, 1999; Lincoln \& Guba, 1985; Maxwell, 1992).

Because the strategy as practice perspective is interested in situated, concrete activity (Whittington, 2003), the strategizing perspective needs to trace the detailed micro-activities which constitute the day-to-day activities of individuals that make up strategy (Balogun et al., 2003; Johnson et al., 2003). To structure the volume of data the raw material was interpreted into activities that were the smallest unit of analysis. All relevant activities were entered chronologically into an activity file. The next step of structuring the description of the activities was to organize the activities into categories. The categories provide a useful descriptive means of decomposing the data into manageable units for the forthcoming analysis (Taylor \& Bogdan, 1984). The activity files as well as the categories only aid in structuring the raw data; however, both strategies represent an effective means to increase the internal validity of the underlying database (Miles \& Huberman, 1994).

In line with the research question about the interactions between senior and middle management within shaping strategy, three a priori constructs derived from the literature were used to start analysing the data. With regard to the rich, underlying research field, the a priori constructs helped to guide the initial coding process and the data analysis (Eisenhardt, 1989). By constantly iterating back and forth between these theoretically derived concepts and the empirical data, three refined concepts emerged from the data. The refined concepts include gathering strategic input, negotiating 
strategic issues and decision-making activities. In the following, these concepts supported the emergence of coding rules that helped in finding more detailed managerial activities without reducing the richness of the data (Poole et al., 2000; Strauss \& Corbin, 1990; Van Maanen, 1979). As the coding progressed, emerging categories and patterns were sought after (Langley, 1999; Miles \& Huberman, 1994).

\section{Data analysis}

Coding the data led to categories that included various types of activities through which managers gather strategic input, negotiate further activities and decide on the issue (see Table 1).

\section{Gathering strategic input}

Gathering strategic input includes the activities of the middle managers to recognize and to identify new issues, as well as to gain information about the topic. In changing environments, the middle managers deal with novel insights, unfamiliar cause-effect relationships, and new experiences. Therefore, to start implementing the personnel development the middle managers used their positions within the organization and their external contacts to gather detailed information about their novel issues. The empirical findings illustrate how the strategic input was gathered by middle managers. They read the requirements given by the Ministry, worked out guidelines and looked at the activities of other administrations concerning personnel development. The middle managers succeeded in gathering a great deal of information about the topic by attending meetings and conferences, exchanging ideas with experts outside of the organization, or attending the activities in the Ministry:

I know a lot of people in other organizations (...) concerned with personnel development. We always knew where to draw information from and were very well informed at all times.

(Middle manager interview)

Not knowing the right people is a real problem around here.

(Middle manager interview)

Gathering information on strategic issues also included middle managers reporting central issues and relevant topics to the senior management. In reporting these strategic issues, the middle managers took advantage of their formal access to official strategy meetings. These middle managers acquired 
a high level of influence within the process through their capacity to build on formal authority or on informal positions in order to seek detailed information, promote their activities, and mobilize others. One middle manager, for example, had been working in the Ministry and still was in good contact with the managers there so he could ask for information or details. Moreover, he was always meeting with experts working with personnel development in other administrations and used every means to discuss personnel development practices. Therefore, the middle manager mobilized others to sponsor his work through providing information or advice.

Moreover, the middle managers attended workshops and seminars to gain further information on the personnel development practices. Therefore, the middle managers justified and defined new concepts, evaluated the merits of new proposals, searched for new opportunities, and proposed programs to senior management.

\section{Negotiating activities}

The negotiation activities intended to coordinate divergent aims and interests, interpret and understand new issues, and convince others of the merit of new ideas. The negotiation activities describe the coordination of interests in terms of exchanging information with colleagues, integrating experts, and negotiating about what was expected in the changing organization. While the middle managers were unable to pursue the process alone in the beginning, they involved more experts to strengthen their position in the following negotiations and to enhance acceptance for the issue.

... my colleague and I tried to seek assistance (...) - not to build up a network - that would be too much, but to find allies ... We then contacted two more middle managers; they had participated in the Ministry in working on the draft of personnel development. And we agreed that we should start something.

(Middle manager interview)

Especially in the beginning, the middle managers had no concrete ideas about how to implement the personnel development. Therefore, the middle managers suggested setting up a working group, in order to involve more experts in the process.

This is so to say an experience (...) that one can achieve even more with teams, three to five people, than if one tries to implement something all alone within the regular hierarchical structures, (...) especially if it is about change. 


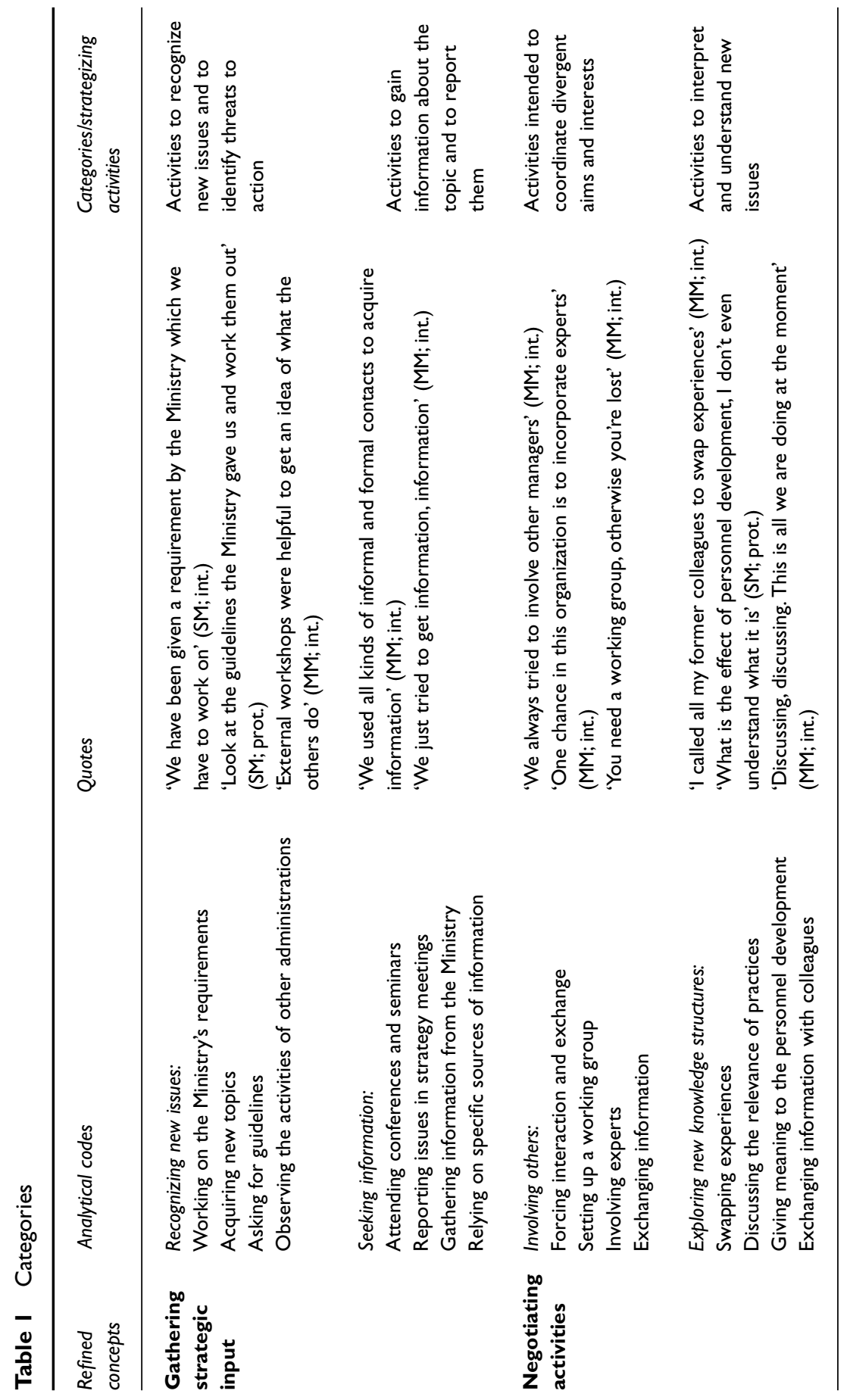




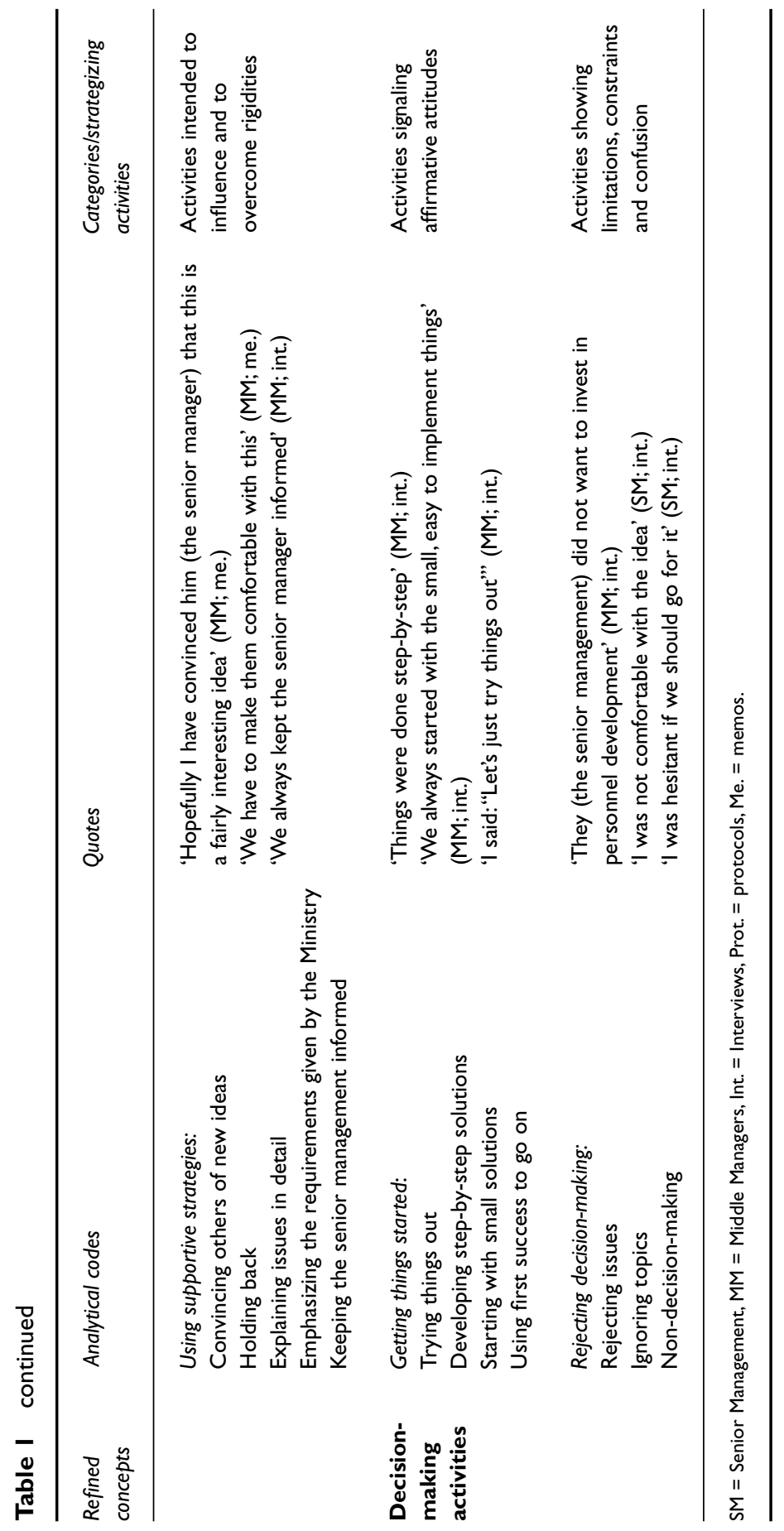


In addition to the contacts with these other working group members, the middle managers also decided to involve further people in the process and ask experts from outside the organization to be part of the project. Experts from different functional areas, managers having decision-making authority concerning personnel development, and the stakeholders within the organization were all asked to join the working group and to take part in discussing the issue. The enhanced interactions with other middle managers facilitated the exchange of interests, opinions, and knowledge and enabled the development of initial recommendations about how to implement the personnel development.

... one must try to bring together expertise from different organizational units with different interests (...), and contact other colleagues, work out suggestions, and then go to tell the senior management.

(Middle manager interview)

The expertise enlisted from inside and outside of the organization included managers from two private organizations who were experienced in personnel development. They were invited to present their experiences with personnel development and to discuss different ways of implementing personnel development. In sum, the findings show that there was a need to create a better understanding of personnel development and its relevance and effects for the organization. Building up a better understanding of the issue was helpful in securing senior managers' attention towards personnel development.

Therefore, the case shows that the managers built support for the issue through influencing the course of action, convincing others of the merit of new issues, and keeping the senior management informed. However, the middle managers could not get much attention from the senior management for their initiatives. The data illustrate that in addition to engaging their colleagues on the higher hierarchical level and mobilizing additional resources, the middle managers also tried to legitimize their strategic input by focusing on the requirements given by the Ministry.

That was the point where we decided to put more emphasis on the requirements given by the Ministry (. . .) Perhaps also to make clear to senior management that it [personnel development] is not at all a weird idea from a few office workers and the staff council, but that (...) personnel development is an accepted tool in the Ministry and other public organizations. 
The findings show that the middle managers as longstanding members of the organization knew who could help advocate the issue, and had a good sense of the game being played inside the organization. They exploited their knowledge to build support for implementing personnel development. The middle managers persisted on their initiatives to overcome rigidities and took advantage of timing to decide when to start initiatives and when to hold back.

Because my colleague is an old hand at this, he knows exactly when the time is ripe for new ideas and when to keep his mouth shut. You don't have a chance if you don't stick to that.

(Middle manager interview)

\section{Decision-making activities}

The constitution of a formal committee is part of how decision-making is organized between all managers involved. The formal committee is the setting for exchanging knowledge, discussing new issues, and making decisions. The decision-making activities include, on the one hand, affirmative attitudes towards implementing personnel development. On the other hand, activities also show limitations, constraints and confusion concerning the issue. At the beginning of the process, the senior management ignored the attempts to introduce personnel development because they were hesitant as to whether it could be helpful in a public administration. Later, the senior management rejected the introduction of personnel development due to scarce resources. Despite this lack of support from the senior management for personnel development, the middle managers continued with their initiatives, starting with small easy to implement proposals.

... we decided just to start a project, (. . .) just doing it step-by-step, to gather initial experiences with it, (...) and at the end of such a pilot's phase, the decision should be made whether to replace it or to continue with it.

(Middle manager interview)

Personnel development is a novel and unfamiliar topic to the senior management who do not have much experience with it. By starting the implementation with activities and proposals that are short-term and incremental in character, the middle managers secured senior management's support for rapid implementation despite scarce resources. 
Take the workshops, for example - we all were really skeptical if it could work. The workshop was quite new for the administration, never had been there before. Therefore, we contacted senior management again and again, discussed with them, and suggested to try one out (...) Finally, it worked very well; senior management told us that they were really happy with it. So we continued with it (...) and all workshops were supported by senior management.

(Middle manager interview)

The empirical results show that the affirmative attitude of senior management towards the issue is influenced by close contact among the managers involved in the process that enhanced the encouragement of the middle managers to continue with further activities.

\section{Findings}

\section{Strategizing activity patterns}

The data analysis reported above reveals a distinction in the observed strategic activities. The activities of the senior management and middle management differ between activities taking place within the formal committee and interactions being located in more informal settings. Although the interactions between senior and middle management were formally organized in committees, interactions around the committee meetings are obvious in the empirical data. These interactions are informal both in terms of their hierarchical location and dominant meeting routines (see Table 2).

Table 2 Committee-based interactions and informal interactions

\begin{tabular}{lll}
\hline & $\begin{array}{l}\text { Formal committee-based } \\
\text { interactions }\end{array}$ & $\begin{array}{l}\text { Informal interactions around } \\
\text { committee meetings }\end{array}$ \\
\hline Hierarchical location: & - Senior management, middle & - Changing members of middle \\
meeting routines: & - Formal invitations & management and senior manager \\
& - Meeting agenda sent to all & members before the meetings \\
- Official meeting rooms & $\begin{array}{l}\text { Protocols and minutes, } \\
\text { distributed to everyone and } \\
\text { rubber-stamped }\end{array}$ & $\begin{array}{l}\text { Offices, hallways, before other } \\
\text { meetings }\end{array}$ \\
& $\begin{array}{l}\text { Written internal memos or } \\
\text { information by phone, mail or } \\
\text { face-to-face }\end{array}$ \\
\hline
\end{tabular}


The results show that some of the activities take place in the committee, while other activities are more visible in informal interactions. In the case history, the committee includes the senior management, the middle managers, and the stakeholders. For the committee, well-organized and strict meeting routines exist, including invitations, working agendas, protocols and minutes to document the decisions made. However, outside of the committee, informal interactions between senior and middle management are apparent in the data. These informal interactions take place as loosely scheduled meetings and involve both middle and senior managers. This close informally organized interaction can be characterized as one-on-one meetings or behindthe-scene-discussions. The results of the informal interactions were not written down in protocols or minutes but spread by mail, phone or face-toface communication.

In this study, the distinction between formal committees and informal interactions is important because the strategizing activity patterns of gathering strategic input, negotiating activities, and decision-making activities, and their implications differ with regard to the type of interaction (see Table 3).

Table 3 Strategic conversation as informal strategizing activity patterns

\begin{tabular}{|c|c|c|}
\hline $\begin{array}{l}\text { Strategizing activity } \\
\text { patterns }\end{array}$ & $\begin{array}{l}\text { Committee as formal } \\
\text { practice }\end{array}$ & $\begin{array}{l}\text { Informal interactions: } \\
\text { Strategic conversation }\end{array}$ \\
\hline Gathering strategic input: & $\begin{array}{l}\text { Middle managers reporting } \\
\text { issues to senior management } \\
\text { and stakeholders }\end{array}$ & $\begin{array}{l}\text { Middle managers recognizing, } \\
\text { identifying, and recommending } \\
\text { new issues } \\
\text { Senior management asking for } \\
\text { information }\end{array}$ \\
\hline Negotiating activities: & $\begin{array}{l}\text { Discussing and coordinating } \\
\text { divergent aims and interests } \\
\text { of managers and stakeholders }\end{array}$ & $\begin{array}{l}\text { Middle managers asking for the } \\
\text { senior management's } \\
\text { preferences } \\
\text { Middle managers and senior } \\
\text { managers negotiating implications } \\
\text { of concepts and discussing rejecting } \\
\text { attitudes } \\
\text { Middle managers and senior } \\
\text { managers interpreting new issues, } \\
\text { defining a meaning }\end{array}$ \\
\hline Decision-making activities: & $\begin{array}{l}\text { Official decisions made by } \\
\text { the committee about } \\
\text { concepts and instruments }\end{array}$ & $\begin{array}{l}\text { Senior management signaling } \\
\text { positive or negative attitudes }\end{array}$ \\
\hline Implications & $\begin{array}{l}\text { Served as official working } \\
\text { agenda, legitimized next steps }\end{array}$ & $\begin{array}{l}\text { Affected the day-to-day work, } \\
\text { encouraged searching for new issues }\end{array}$ \\
\hline
\end{tabular}


The first type of interaction involves the committee, formally organizing the shaping of strategy implementation, with managers and stakeholders gathering strategic input, discussing an issue, and finally making a decision. The decisions made in the committee serve as the official agenda for the following work of the middle managers. However, the findings show that the formally committee-oriented interaction between senior and middle management is complemented by a second type of interaction. The results suggest that the managers act within a context composed of rules, routines, values, and norms that constrain what they can do. Thus, the data show that these rules, values, and norms are not negotiated within the formal committee:

We all have not been here long enough to know what can be implemented and what can't. We have always discussed ideas amongst ourselves but we also clearly know when we can't get something to work, so we don't even need to try it. That's why we've only discussed the proposals in the committee that we knew would go through.

(Field note)

The negotiation of opinions and attitudes between senior and middle management therefore takes place in informal interactions. The findings make clear that these unofficial 'strategic conversations' propelled the strategic issues forward. Thus, there is a need for a deeper understanding of the dynamics of the committee as formal practice and the strategic conversation as informal practice in the shaping strategy.

\section{Strategic conversations}

The findings show that the strategic conversations represent a specific informal interaction between senior and middle managers around the committee. The strategic conversations are an important part in the interaction between middle and senior management as they enable the discussion of differences in viewpoints, attitudes, and opinions beyond hierarchical structures (Westley, 1990). The managers negotiate issues and establish opinions, express cognitions, articulate their perceptions of the environment, and legitimate their individual strategic actions (Boje, 1991, 1995; SamraFredericks, 2003). The strategic conversations frame the committee-based interaction and complement these formal interactions between senior and middle management through three micro-level mechanisms. These mechanisms entail generating an understanding of the issue, aligning towards an issue, and making prearrangements (see Figure 1). 


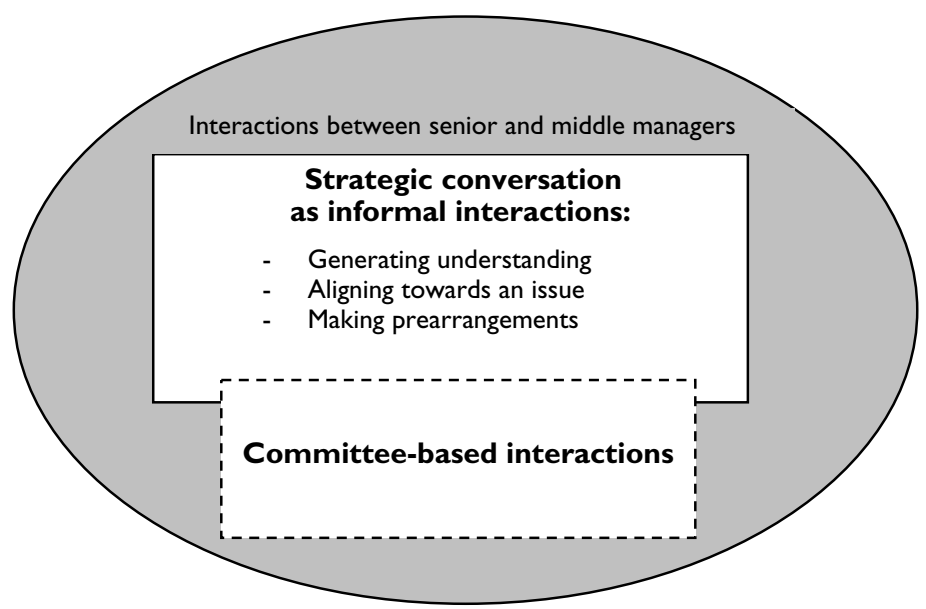

Figure I Strategic conversation

First, strategic conversation is characterized by the micro-level mechanism of generating an understanding. Especially with regard to complex, uncertain issues, the data indicate that middle managers schedule informal contacts with senior managers to inform them about strategic issues, the state of the art in ongoing projects, and decisions to be made in the forthcoming committee:

It was a major task to keep senior management informed. By the fact that we always prepared the decisions very well and told our senior management about it in time, we received their agreement on our decisions.

(Middle manager interview)

The informal contacts to senior management that I have scheduled over the years have been of high value .. I I have been able to overstep many official boundaries.

(Middle manager interview)

With regard to the subsequent steps and planned activities, the middle managers informed the senior managers before every committee about what was going to be discussed. The middle managers give explanations, justifications, or clarifications for what they are doing or the senior managers may request these explanations. The case provides many examples of such interactions. For instance, one middle manager and one senior manager showed 
up 10 minutes earlier before the meeting for another project to resolve an issue for the committee meeting in the following week. A topic on the agenda regarded the use of a workshop, something which had never been introduced as a personnel development practice before. The middle manager used these 10 minutes to describe the topic to the senior manager, to legitimize it according to the Ministry's requirements and to justify why he thought the topic could be of interest for them. The senior manager answered that he believes in using workshops and that he had already informed himself about the topic. During the committee meeting the topic was discussed amongst all participants and supported and decided upon by the senior manager.

This study shows that the strategic conversation refers to generating a shared understanding of an issue through discussion of different ideas and evidence, and exploration of beliefs and feelings. Through this conversation, people seek to comprehend the situation and establish cause-effect relationships. By generating an understanding, the managers provide proposals, work to make sense of the issue, and move the matter forward.

Second, strategic conversation is also characterized by the micro-level mechanism of the strategists aligning towards an issue. The strategic conversation is characterized by the signals, which the senior managers give out when reacting to the activities of middle managers. Two weeks before a committee meeting, for example, one middle manager and one of the senior managers went to a seminar about double-entry bookkeeping. On the way there the middle managers used the opportunity to discuss a personnel development practice and its relevance for the organization with the senior manager. The next day the middle manager sent an email to all the other participants that the senior manager had only shown little interest in the topic and moved on quickly. The middle manager recommended in the email that they wait with this topic. Consequently, the topic was not put on the agenda of the next committee meeting. This example shows how middle managers took advantage of their close proximity to senior management by recognizing and interpreting the senior management's reactions to new issues in the run-up to decisions:

Most of the time he [senior manager] thinks our suggestions are quite good. But when he hesitates or is skeptical then I already know that we should take a different route. I pass on his reactions on to the others (middle managers) and we then know where we stand.

(Middle manager interview)

If senior management had objections towards an issue, we always discussed that before committee meetings. Never in official meetings.

(Middle manager interview) 
Through the frequent informal exchange about the behaviors, attitudes, and comments of their senior managers, the managers read their senior management's intent and disseminated these intentions among the managers involved. Through the strategic conversation, senior managers aligned themselves for or against an issue. Aligning is a way of giving signals about priorities and future attitudes towards a strategic issue. The supportive or unsupportive attitudes of the senior management were taken into account by the middle managers, and they often orientated their strategic activities towards them. Thus, the strategic conversation represents an arena legitimizing frame in which middle managers can test out their thinking with their senior managers and move towards a common understanding.

Third, strategic conversation is characterized by making prearrangements, entailing assertions, expressions, and declarations to bring about an end to a discussion. Closure involves letting go of what no longer works and a continuation of what does work. The findings show that the strategic conversation results in prearrangements being made between the middle managers and the senior management:

We were always close to the senior management. I already think that this is really helpful $(. .$.$) in the run-up to the decision (...) For$ example, if it was reported that in meetings with the senior management someone has expressed any doubts or reservations, then that was considered immediately (...) A subtle hint from senior management and we would cancel and change direction.

(Middle manager interview)

These subtle hints from senior management were taken seriously in that unsupported activities were modified or not added into the committee. Positive attitudes by the senior management led to the middle managers making their concepts more concrete and adding them into the committee's discussions.

Every suggestion to the committee and every little activity was adjusted before ... and we always knew how the proposal would be decided within the next committee meeting ...

(Middle manager interview)

When senior management made a positive decision on a topic, they always kept their word.

(Middle manager memo) 
These prearrangements determine how to decide an issue or to present a proposal. Through their prearrangements, the middle managers gained certainty about the kinds of issues that were going to be supported by the senior management. The prearrangements were useful to build up confidence and to gain the support of the senior manager. Therefore, the prearrangements are not only directed at affecting senior management's attention but they also set the frame for further strategic activities:

If the senior management agrees with one of our proposals, then we know that we can keep doing what we've been doing. We don't really need any special permission for further activities. Rather when one proposal goes through, then that holds true for all other proposals. This makes our work much easier.

(Memo)

In sum, the generation of a shared understanding and the legitimation of activities through strategic conversations in turn creates the conditions that enable prearrangements. Particularly with regard to complex, uncertain issues, the findings show that both activities contribute to prearrangements between the management levels by developing an alignment towards strategic issues.

\section{Discussion}

In sum, the study shows the strategic conversation as informally scheduled interactions, embedded within the formal committee-based relationships between senior and middle managers. They are beneficial within shaping strategy as they give support to the flow of discussion. This study provides three specific contributions to the strategy practice perspective. First, discussing the relations between senior and middle managers, how they act and interact and what situated practices and tactics they draw upon, is an innovative way to demonstrate that all members of the organization are, in fact strategizing. Second, by taking into account the links between formal and informal activities, this article presents an appropriate, if not a more complete way of looking for practices. By focusing on the day-to-day activities, this study reveals the underlying micro-mechanisms inherent to the strategic conversation. Third, this study describes three micro-mechanisms that determine strategic conversation and hence contributes to better understanding of what happens in behind-the-scene-discussions when people are strategizing. The results suggest that the strategic conversation with its informally, loosely 
scheduled interactions between the senior and middle management helps middle managers to recognize and interpret the senior management's alignment to an issue and to orientate their strategic activities towards these signals. The strategic conversation results in prearrangements which contribute to enhancing the flow of discussion between the management levels by developing a shared understanding and commitment towards a strategic issue.

This study indicates the committee as formal practice that organized the interactions between the managers in a way that promoted the integration of divergent aims and interests and supported decision-making. By involving all participants, the committee is seen as vitally important in dealing with resistance by contributing to the regulation of different aims and interests (Amason, 1997; Korsgaard et al., 1995). However, the data show that the negotiation of different meanings and viewpoints between the management levels in order to reshape the strategic context is not located 'within' the committee but takes place in strategic conversations. This research emphasizes the importance of strategic conversations and provides some relevant insights into how middle managers and senior managers use informally organized contacts to generate an understanding, legitimize further activities through alignments and make prearrangements. Although the informal interactions have a great disruptive potential because they are less easy to control, it has long been suspected that the informal conversations are as important as the formal interactions. One argument supporting the evident importance of informal conversation is made in the point that informal practices may have a greater creative potential for developing issues that do not derive from the established issues of the organization (Hendry \& Seidl, 2003). Like other studies, this study shows the political elements of shaping strategy. It shows the importance of both the back-stage activities, here the strategic conversation, and the front-stage activities, here the interactions organized within the committee. The backstage activity can be understood as a preparation for front-stage activity and it is used to manipulate these front-stage activities (Balogun et al., 2005).

Within the overall patterns of strategic conversation, similarities can be found in relation to other studies, but the findings also demonstrate differences to previous research. First, from the perspective of the middle managers the strategic conversation represents generating an understanding of the new issue. Generating an understanding includes providing proposals such as describing and explaining issues, and articulating perceptions of the environment. In line with the issue selling literature (Dutton \& Ashford, 1993; Dutton et al., 1997, 2001), the findings show that the provision of proposals presents the strategizing activities with which managers start up their ideas, actions and demands and with which they direct senior management's attention towards an issue. The activities undertaken in order to provide an 
understanding are tactical but it is a softer tactic in contrast to issue selling. Instead of selling and promoting issues, the middle managers merely provide proposals to the senior managers. If the issue is rejected through the senior manager's failure to signal support, the issue is dropped and not promoted any further.

Second, the strategic conversation is characterized by the senior manager's alignment towards an issue. Aligning is a way of giving signals about priorities, with the middle managers interpreting the senior management's reactions to a strategic proposal. Like other studies (Balogun, 2003; Balogun \& Johnson, 2004), this research suggests that senior manager's alignments are interpreted by the middle managers as a specific attitude towards a strategic issue that legitimizes continuing on with a strategic issue and undertaking further initiatives. Both the studies by Floyd and Wooldridge (1997) and Floyd and Lane (2000) as well as the present study demonstrate that alignment is a necessary precursor to further initiatives because the middle managers gain certainty about the kinds of issues that were going to be supported by the senior management. The more utterly the senior managers support strategic issues, the more the signals about senior management's priorities are considered by the managers. From the perspective of the middle managers, these alignments enhance the confidence, support and acceptance they need to push the strategy implementation forward. In sum, the senior management's alignments towards an issue set the frame for further initiatives undertaken by the middle managers.

Third, the strategic conversation is characterized by prearrangements. The findings show that the prearrangements are an important micromechanism that determines the interactions between the middle managers and the senior managers. The prearrangements are not only directed at influencing senior management's attention towards an issue but they also set the frame for further strategic activities. The studies by Ashford et al. (1998), Dutton and Ashford (1993) and Dutton et al. (2002) examine the context cues lower-level managers use in assessing whether or not to undertake initiatives. An actor's willingness to start initiatives is affected by the processes of issue selling, whereby the managers assess the context cues. Recent studies focus on the hierarchically organized interactions between the senior and middle management levels showing that senior management's task is to set the context for further decisions and that middle managers examine the context for championing initiatives (Floyd \& Lane, 2000; Floyd \& Wooldridge, 1997). Significantly, the present study differs from these studies because it suggests that the senior management does not set the strategic context before middle managers give strategic input, but they negotiate the scope of new issues within strategic conversation. Thus, the 
strategic context is the result of informally scheduled conversation processes in which both the senior management and the middle management play a pivotal role.

In sum, the findings show that the strategic conversations are beneficial within shaping strategy as they frame the committee as strategic practice and give support to the flow of discussion.

\section{Implications for future research}

This study is a longitudinal single case study observing the implementation of personnel development in a public administration. The single case study focuses in considerable depth on how strategy implementation evolves in a public administration. Viewed narrowly, this research contributes to understanding middle managers and senior managers with both their committeebased interactions and their informal interactions in a public administration. More broadly, the findings help to unravel the interactions between senior management and middle management and contribute to the development of strategy research (Eisenhardt, 1989).

Like much of the literature, this research examined patterns of interactions within management levels in only one organization and in one form of a new strategy. Although the study has only focused on a particular instance, the context gives the findings a broader relevance. There are a great deal of studies researching into strategy making in public sectors (e.g. Gioia et al., 1994; Thomas et al., 1993) showing, for example, the inadequacies of formal practices and rational planning systems in public settings (Hardy et al., 1983; Langley, 1988, 1989). However, the use of committees in public administration settings is common when they are faced with new issues. Although the findings confirm that the committee is helpful in structuring the formal interactions between managers and stakeholders, the study leads to the more general conclusion that the committee-based interactions between middle and senior management are pushed forward in important informally scheduled strategic conversations. The strategic conversations lead to prearrangements that feed into the committee by setting the strategic context for the formal decision-making routines.

The German administration studied faced having to cope with a new and complex environment that demanded reform processes compounded by its long tradition with a strong structure. This description fits many public sector organizations. Therefore, like other recent studies this case reveals the role middle managers play in the public sector (Currie, 1999, 2000). Even in top-down and directive organizations, middle managers are empowered to 
have more control over decision-making and more chances to solve problems than they previously have acknowledged (Currie \& Procter, 2001).

However, as with any single case study research, the generalizability of the findings needs to be established through further research. More research efforts are needed to understand the interaction of both middle and senior management. The research enables some tentative propositions about the relevance of committees and the implications of strategic conversation for shaping strategy. To make further progress, researchers need to develop a greater understanding of how specific aspects of strategic conversation have implications for how managers facilitate strategic change in organizations.

\section{Acknowledgements}

I am very grateful to Julia Balogun, Paula Jarzabkowski, and David Seidl and the three anonymous reviewers for their insightful comments. I am especially indebted to Reviewer 1 for helpful advice in developing this article. Subsequently, the article benefited from the thoughtful and developmental comments of Julia Balogun on various drafts of this article.

\section{References}

Amason, A.C. Good and bad conflict in strategic decision making. In V. Papadakis \& P. Barwise (Eds), Strategic decisions. Dordrecht: Kluwer, 1997, pp. 51-63.

Ashford, S., Rothbard, N.P., Piderit, S.K. \& Dutton, J.E. Out on a limb: The role of context and impression management in selling gender-equity issues. Administrative Science Quarterly, 1998, 43, 23-57.

Balogun, J. From blaming the middle to harnessing its potential: Creating change intermediaries. British Journal of Management, 2003, 14, 69-83.

Balogun, J. Managing change: Steering a course between intended strategies and unanticipated outcomes. Long Range Planning, 2006, 39, 29-49.

Balogun, J. \& Johnson, G. Organizational restructuring and middle manager sensemaking. Academy of Management Journal, 2004, 47(4), 523-49.

Balogun, J. \& Johnson, G. From intended strategies to unintended outcomes: The impact of change recipient sensemaking. Organization Studies, 2005, 26(11), 1573-602.

Balogun, J., Gleadle, P., Hope Hailey, V. \& Willmott, H. Managing change across boundaries: Boundary-shaking practices. British Journal of Management, 2005, 16, 261-78.

Balogun, J., Huff, A.S. \& Johnson, P. Three responses to the methodological challenges of studying strategizing. Journal of Management Studies, 2003, 40(1), 197-224.

Balogun, J., Jarzabkowski, P. \& Seidl, D. Strategizing activity and practice. In V. Ambrosini \& M. Jenkins (Eds), Advances strategic management. Basingstoke: Palgrave, 2007, pp. 196-212.

Bartlett, C.A. \& Ghoshal, S. Beyond the m-form. Toward a managerial theory of the firm. Strategic Management Journal, 1993, 14, 23-46.

Bartlett, C.A. \& Ghoshal, S. Changing the role of top management. Beyond strategy to purpose. Harvard Business Review, 1995, 73(3), 132-42. 
Boje, D.M. The storytelling organization. A study of story performance in an office-supply firm. Administrative Science Quarterly, 1991, 36, 106-26.

Boje, D.M. Stories of the storytelling organization. A postmodern analysis of Disney as 'Tamara-land'. Academy of Management Journal, 1995, 38, 997-1017.

Bower, J.L. Managing the resource allocation process. Boston, MA: Harvard Business School Press, 1970.

Bower, J.L. Process research on strategic decisions. A personal perspective. In V. Papadakis \& P. Barwise (Eds), Strategic decisions. Dordrecht: Kluwer, 1997, pp. 17-35.

Brown, J.S. \& Duguid, P. Knowledge and organization: A social-practice perspective. Organization Science, 2001, 12(2), 198-213.

Burgelman, R.A. Corporate entrepreneurship and strategic management. Insights from a process study. Management Science, 1983, 29(12), 1349-64.

Burgelman, R.A. A process model of strategic business exit. Implications for an evolutionary perspective on strategy. Strategic Management Journal, 1996, 17, 193-214.

Currie, G. The influence of middle managers in the business planning process. A case study in the UK NHS. British Journal of Managmenet, 1999, 10, 141-55.

Currie, G. The public manager in 2010 - The role of middle managers in strategic change in the public sector. Public Money and Management, 2000, 20(1), 17-22.

Currie, G. \& Brown, A.D. A narratological approach to understanding processes of organizing in UK hospitals. Human Relations, 2003, 56, 563-86.

Currie, G. \& Procter, S. Exploring the relationships between HR and middle managers. Human Resources Management Journal, 2001, 11(3), 53-69.

Datta, D.K. \& Rajagopalan, N. Industry structure and CEO characteristics. An empirical study of succession events. Strategic Management Journal, 1998, 19, 833-52.

Dutton, J.E. \& Ashford, S.J. Selling issues to top management. Academy of Management Review, 1993, 18(3), 397-428.

Dutton, J.E. \& Duncan, R.B. The influence of the strategic planning process on strategic change. Strategic Management Journal, 1987, 8, 103-16.

Dutton, J.E., Ashford, S.J., Lawrence, K.A. \& Mider-Rubino, K. Red light, green light: Making sense of the organizational context for issue selling. Organization Science, 2002, 13, 355-69.

Dutton, J.E., Ashford, S.J., O’Neill, R.M. \& Hayes, E. Reading the wind: How middle managers assess the context for selling issues to top managers. Strategic Management Journal, 1997, 18, 407-25.

Dutton, J.E., Ashford, S.J., O’Neill, R.M. \& Lawrence, K.A. Moves that matters: Issue selling and organizational change. Academy of Management Journal, 2001, 44(4), 716-36.

Eisenhardt, K.M. Building theories from case study research. Academy of Management Review, 1989, 4(4), 532-50.

Floyd, S.W. \& Lane, P.J. Strategizing throughout the organization. Managing role conflict in strategic renewal. Academy of Management Review, 2000, 25(1), 154-77.

Floyd, S.W. \& Wooldridge, B. Middle management involvement in strategy and its association with strategic type: A research note. Strategic Management Journal, 1992, 13, 153-67.

Floyd, S.W. \& Wooldridge, B. Dinosaurs or dynamos? Recognizing middle management's strategic role. Academy of Management Executive, 1994, 8(4), 47-57.

Floyd, S.W. \& Wooldridge, B. Middle managements strategic influence and organizational performance. Journal of Management Studies, 1997, 34(3), 465-85.

Forbes, D.P. \& Milliken, F.J. Cognition and corporate governance: Understanding boards of directors as strategic decision-making groups. Academy of Management Review, 1999, 24(3), 489-505.

Ford, J.D. Organizational change as shifting conversations. Journal of Organizational Change Management, 1999, 12, 480-500. 
Ford, J.D. \& Ford, L.W. The role of conversations in producing interntional change in organizations. Academy of Management Review, 1995, 20, 541-70.

Fredrickson, J.W. The strategic decision process and organizational structure. Academy of Management Review, 1986, 11(2), 280-97.

Gephart, R. Succession sensemaking and organizational change: A story of deviant college president. Journal of Organizational Change Management, 1991, 4(3), 35-44.

Gephart, R. Hazardous measures: An interpretive textual analysis of quantitative sensemaking during crises. Journal of Organizational Behavior, 1997, 18, 583-622.

Gioia, D.A. \& Chittipeddi, K. Sensemaking and sensegiving in strategic change initiation. Strategic Management Journal, 1991, 12, 433-48.

Gioia, D.A. \& Thomas, J.B. Identity, image, and issue interpretation: Sensemaking during strategic change in academia. Administrative Science Quarterly, 1996, 41, 370-403.

Gioia, D.A., Thomas, J.B., Clark, S.M. \& Chittipeddi, K. Symbolism and strategic change in academia: The dynamics of sensemaking and influence. Organization Science, 1994, $5(3), 363-83$.

Hardy, C., Langley, A., Mintzberg, H. \& Rose, J. Strategy formation in the university setting. Review of Higher Education, 1983, 6(4), 24-53.

Hart, S.L. An integrative framework for strategy-making processes. Academy of Management Review, 1992, 17(2), 327-51.

Hendry, J. Strategic decision-making, discourse, and strategy as social practice. Journal of Management Studies, 2000, 37, 955-77.

Hendry, J. \& Seidl, D. The structure and significance of strategic episodes: Social systems theory and the routine practices of strategic change. Journal of Management Studies, 2003, 40(1), 175-96.

Hickson, D.J., Butler, R.J., Cray, D., Mallory, G.R. \& Wilson, D.C. Decision and organization - Processes of strategic decision making and their explanation. Public Administration, 1989, 67, 373-90.

Howell, J.M. \& Boies, K. Champions of technological innovation. The influence of contextual knowledge, role orientation, idea generation, and idea promotion on champion emergence. The Leadership Quarterly, 2004, 15, 123-43.

Huy, Q.N. In praise of middle managers. Harvard Business Review, 2001, 79(5), 72-9.

Huy, Q.N. Emotional balancing of organizational continuity and radical change. The contribution of middle managers. Administrative Science Quarterly, 2002, 47, 31-69.

Isabella, L.A. Evolving interpretations as change unfolds: How managers construe key organizational events. Academy of Management Journal, 1990, 33, 7-41.

Jarzabkowski, P. Strategic practices. An activity theory perspective on continuity and change. Journal of Management Studies, 2003, 40, 23-55.

Jarzabkowski, P. Strategy as practice: Recursiveness, adaptation, and practices-in-use. Organization Studies, 2004, 25, 529-60.

Jarzabkowski, P. Strategy as practice: An activity based approach. London: Sage, 2005.

Jarzabkowski, P. \& Seidl, D. Meetings as strategizing episodes in the becoming of organizational strategy. Advances Institute of Management (AIM). Working Paper No. 037, March 2006.

Jarzabkowski, P. \& Wilson, D.C. Top teams and strategy in a UK university. Journal of Management Studies, 2002, 39, 355-81.

Jarzabkowski, P., Balogun, J. \& Seidl, D. Strategizing: The challenges of a practice perspective. Human Relations, 2007, 60(5), 5-27.

Johnson, G. \& Huff, A.S. Everyday innovation/everyday strategy. In G. Hamel, C.K. Prahalad, H. Thomas \& D. O'Neal (Eds), Strategic flexibility: Managing in a turbulent environment. Chichester: Wiley, 1998, pp. 13-27.

Johnson, G., Melin, L. \& Whittington, R. Micro strategy and strategizing. Towards an activity-based view. Journal of Management Studies, 2003, 40(1), 3-22.

Korsgaard, M.A., Schweiger, D.M. \& Sapienza, H.J. Building commitment, attachment, 
and trust in strategic decision-making team: The role of procedural justice. Academy of Management Journal, 1995, 38(1), 60-84.

Langley, A. The roles of formal strategic planning. Long Range Planning, 1988, 21(3), 40-50.

Langley, A. In search of rationality: The purposes behind the use of formal analysis in organization. Administrative Science Quarterly, 1989, 34, 598-631.

Langley, A. Strategies for theorizing from process data. Academy of Management Review, 1999, 24(4), 691-710.

Langley, A., Mintzberg, H., Pitcher, P. \& Posada, E. Opening up decision making. The view from the black stool. Organization Science, 1995, 6(3), 260-79.

Lee, T.W. Using qualitative methods in organizational research. London: Sage, 1999.

Leonard-Barton, D. A dual methodology for case studies. Synergistic use of a longitudinal single site with replicated multiple sites. Organization Science, 1990, 1(3), 248-66.

Lincoln, Y.S. \& Guba, E.G. Naturalistic inquiry. London: Sage, 1985.

Mantere, S. Strategic practices as enablers and disablers of championing activity. Strategic Organization, 2005, 3(2), 157-84.

Maxwell, J.A. Understanding the validity in qualitative research. Harvard Educational Review, 1992, 62(3), 279-300.

Miles, M.B. \& Huberman, A.M. Qualitative data analysis: An expanded sourcebook, 2nd edn. Thousand Oaks, CA: Sage, 1994.

Pentland, B.T. Building process theory with narrative. From description to explanation. Academy of Management Review, 1999, 24(4), 711-24.

Poole, M.S., Van de Ven, A.H., Dooley, K. \& Holmes, M.E. Organizational change and innovation processes: Theory and methods for research. New York: Oxford University Press, 2000.

Quinn, J.B. Strategic change: 'Logical incrementalism'. Sloan Management Review, 1978, pp. 7-21.

Quinn, J.B. Strategies for change: Logical incrementalism. Homewood, IL: Irwin, 1980.

Regnér, P. Strategy creation in the periphery: Indicative versus deductive strategy making. Journal of Management Studies, 2003, 40(1), 57-82.

Richards, L. Handling qualitative data. London: Sage, 2005.

Rouleau, L. Micro-practices of strategic sensemaking and sensegiving: How middle managers interpret and sell change every day. Journal of Management Studies, 2005, 42(7), 1413-42.

Samra-Fredericks, D. Strategizing as lived experience and strategists everyday efforts to shape strategic direction. Journal of Management Studies, 2003, 40(1), 142-74.

Strauss, A. \& Corbin, J. Basics of qualitative research: Grounded theory procedures and techniques. London: Sage, 1990.

Taylor, S.J. \& Bogdan, R. Introduction to qualitative research methods: The search for meaning, 2nd edn. New York: Wiley, 1984.

Thomas, R. \& Dunkerley, D. Careering downwards? Middle managers' experiences in the downsized organization. British Journal of Management, 1999, 10, 157-69.

Thomas, J.B., Clark, S.M. \& Gioia, D.A. Strategic sensemaking and organizational performance: Linkages among scanning, interpretation, action and outcomes. Academy of Management Journal, 1993, 36, 239-70.

Van Maanen, J. The fact of fiction to organizational ethnography. Administrative Science Quarterly, 1979, 24, 539-50.

Wayne, S.J., Liden, R.C., Graf, I.K. \& Ferris, G.R. The role of upward influence tactics in human resource decisions. Personnel Psychology, 1997, 50, 979-1006.

Westley, F.R. Middle managers and strategy: Microdynamics of inclusion. Strategic Management Journal, 1990, 11, 337-51.

Whittington, R. Strategy as practice. Long Range Planning, 1996, 29(5), 731-5. 
Whittington, R. The work of strategizing and organizing: For a practice perspective. Strategic Organization, 2003, 1(1), 117-25.

Whittington, R. Completing the practice turn in strategy research. Organization Studies, 2006, 27(5), 613-34.

Whittington, R., Jarzabkowski, P., Mayer, M., Mounoud, E., Nahapiet, J. \& Rouleau, L. Taking strategy seriously: Responsibility and reform for an important social practice. Journal of Management Inquiry, 2003, 12, 396-409.

Yin, R.K. Case study research: Design and methods, 3rd edn. Thousand Oaks, CA: Sage, 2003.

Christina Hoon received her $\mathrm{PhD}$ from the Leibniz University of Hannover, Germany. Currently, she is a lecturer at the Leibniz University of Hannover. Her research interests include strategic and organizational change processes with a particular focus on strategic processes, strategy and strategizing in public administrations, as well as on the role of middle managers in strategy formulation and implementation. She has worked recently on innovation and methodological issues in qualitative research. [E-mail: hoon@mbox.ifb.uni-hannover.de] 